\title{
Polityka Arabii Saudyjskiej i Stanów Zjednoczonych wobec wojny domowej w Syrii - zbieżność czy rozbieżność interesów?
}

Wojna domowa w Syrii jest jednym z najpoważniejszych konfliktów na Bliskim Wschodzie od wielu lat. Konflikt, który początkowo miał charakter wewnętrzny, obecnie jest konfliktem umiędzynarodowionym, ponieważ w Syrii krzyżują się interesy nie tylko mocarstw światowych, takich jak Stany Zjednoczone, Federacja Rosyjska, Francja czy Wielka Brytania, ale także interesy państw Bliskiego Wschodu: Iranu, Arabii Saudyjskiej, Izraela, Libanu, Turcji czy Jordanii. Początkowo sytuacja w Syrii rozwijała się podobnie jak w innych państwach regionu, które zostały objęte syndromem „Arabskiej Wiosny”, a społeczność międzynarodowa spodziewała się, że podobnie jak w przypadku innych dyktatorów: Ben Alego, Hosniego Mubaraka czy Muammara al-Kaddafiego, Baszar al-Asad zostanie pozbawiony władzy ${ }^{1}$.

Do pierwszych wystąpień w Syrii doszło pod koniec stycznia 2011 r., jednak nasilenie protestów nastąpiło w lutym i marcu tegoż roku, kiedy to 15 marca tysiące demonstrantów zgromadziło się w Aleppo, Al-Hasace, Darze, Dajr az-Zaurze i Hamie w ramach zorganizowanego drogą internetową „Dnia Gniewu”2. Wśród demonstrantów znaleźli się przede wszystkim aktywiści, dziennikarze, pisarze, prawnicy, młodzi pracownicy naukowi oraz rodziny osób przetrzymywanych bez wyroków w syryjskich więzieniach ${ }^{3} .16$ marca 2011 r. władze syryjskie siłą rozproszyły demonstrujących, a także rozpoczęła się seria zatrzymań syryjskiej opozycji.

1 R. Ożarowski, Motywacje i interesy państw zaangażowanych w wojnę w Syrii, [w:] Bliski Wschód między konfliktem a stabilizacją, red. J. Marszałek-Kawa, R. Podgórzańska, J. Piątek, Toruń 2017, s. 159.

2 J. Zdanowski, Bliski Wschód 2011: bunt czy rewolucja?, Kraków 2011, s. 20.

3 Syria sends tanks onto street, http://www.aljazeera.com/news/middleeast/2011/04/20114 255333825461.html [dostęp: 7.05.2018]. 
Należy zwrócić uwagę na uwarunkowania konfliktu, który jest skutkiem sytuacji wewnętrznej w Syrii spowodowanej wieloletnimi rządami partii Baas. Od czasu przejęcia władzy przez partię Baas w latach 60. XX wieku dochodziło do naruszeń praw człowieka, w tym aresztowań przeciwników reżimu, którzy byli przetrzymywani bez procesu sądowego, a także byli torturowani przez siły bezpieczeństwa. Autorytarny reżim w Syrii ograniczał wolność prasy, słowa, zgromadzeń i zrzeszeń, a partia Baas sprawowała kontrolę nad mediami i prasą, co wpłynęło na wzrost niezadowolenia społecznego Syryjczyków ${ }^{4}$. Problemy gospodarcze Syrii to kolejny powód, dla którego społeczeństwo wyszło na ulice syryjskich miast w ramach protestu przeciwko al-Asadowi. Gospodarka Syrii oparta jest przede wszystkim na sektorze przemysłowo-wydobywczym, tekstylnym, rolnictwie oraz dochodach z ropy naftowej ${ }^{5}$. Pomimo iż sytuacja gospodarcza w Syrii wyglądała lepiej niż w innych państwach arabskich, takich jak Jemen, to problemami, które dotykały bezpośrednio obywateli Syrii były słabość sektora publicznego, bezrobocie, deficyt budżetowy, korupcja, a także ogromne zadłużenie zagraniczne i sankcje międzynarodowe ${ }^{6}$.

Czynnikiem, który miał znaczący wpływ na pogorszenie sytuacji w Syrii, były konflikty narodowościowe oraz religijne. W będącej państwem arabskim Syrii, zamieszkiwała także liczna grupa Kurdów oraz Ormian; ponad 70\% społeczeństwa stanowili sunniccy muzułmanie, ale państwo zamieszkiwały takie mniejszości wyznaniowe jak: imamici, druzowie, alawici czy ismailici, a także chrześcijanie ${ }^{7}$. Przejęcie władzy przez alawicką rodzinę Asadów spowodowało podział syryjskiego społeczeństwa, w którym uprzywilejowaną pozycję społeczną, jak i również w urzędach państwowych, wojsku i gospodarce uzyskali alawici i szyici. Dodatkowo, konflikt wyznaniowy w Syrii podsycał wprowadzony w latach 70. XX wieku zakaz tworzenia partii politycznych opartych na identyfikacji wyzna-

4 K. Czajkowska, A. Diawoł-Sitko, Systemy polityczne wybranych państw Bliskiego Wschodu, Warszawa 2012, s. 215-216.

5 M. Lakomy, Wewnętrzne i zewnętrzne uwarunkowania wojny domowej w Syrii, „Studia Polityczne" 2012, nr 31, s. 225.

6 K. Czajkowska, A. Diawoł-Sitko, op.cit., s. 217-221.

7 F. Jomma, System polityczny Syrii a „Arabska Wiosna Ludów”, [w:] Bunt czy rewolucja? Przemiany na Bliskim Wschodzie po 2010 roku, red. K. Górak-Sosnowska, K. Pachniak, Łódź 2012, s. 124. 
niowej, a powstałe wówczas nielegalnie ugrupowania, takie jak Bractwo Muzułmańskie, uważały rodzinę Asadów za heretyków ${ }^{8}$.

Znaczącą rolę w obecnym konflikcie syryjskim miał czynnik militarny. Większość syryjskiego uzbrojenia stanowił sprzęt produkcji radzieckiej i rosyjskiej, szczególnie jeśli chodzi o sprzęt używany przez wojska lądowe i powietrzne9 ${ }^{9}$. Pomimo że, syryjski reżim wydawał na obronę niewielkie kwoty, to potencjał militarny posiadany wówczas przez reżim Asada wydawał się wystarczający do stłumienia buntów wewnętrznych ${ }^{10}$. Ważnym jest to, że reżim w Damaszku posiada broń chemiczną (gaz musztardowy i sarin), a także posiada zdolność przenoszenia tej broni.

Głównym celem artykułu jest wskazanie na zbieżności i różnice w polityce Arabii Saudyjskiej i Stanów Zjednoczonych w polityce wobec toczącej się od kilku lat wojny w Syrii, która stała się miejscem ścierania interesów nie tylko mocarstw globalnych, ale także państw uznawanych do tej pory za sojuszników. Artykuł ma także na celu odpowiedź na kilka kluczowych pytań badawczych: Czym uwarunkowane jest saudyjskie i amerykańskie zaangażowanie w wojnę domową w Syrii? Czy Rijad i Waszyngton podejmowały wspólne działania mające na celu zakończenie konfliktu w Syrii? Jakie były rozbieżności w polityce Arabii Saudyjskiej i Stanów Zjednoczonych wobec wojny syryjskiej? Jaka była efektywność działań podejmowanych przez Arabię Saudyjską i Stany Zjednoczone w Syrii? Niniejszy artykuł stanowi próbę odpowiedzi na te pytania w oparciu o przede wszystkim polskojęzyczną literaturę przedmiotu.

\section{Zbieżności i rozbieżności w polityce Arabii Saudyjskiej i Stanów Zjednoczonych wobec wojny domowej w Syrii}

Królestwo Arabii Saudyjskiej już od początkowej fazy konfliktu działało aktywnie na arenie międzynarodowej w sprawie syryjskiej. Rijad wzywał Baszara al-Asada do oddania władzy, jednak syryjski dyktator zignorował wezwania, co przyczyniło się do podjęcia działań przez Arabię Saudyjską

8 Z. Landowski, Islam: nurty, odtamy, sekty, Warszawa 2008, s. 175.

9 A.H. Cordesman, If Its Syria: Syrian Military Forces and Capabilities, s. 8-9, http://csis. org/files/media/csis/pubs/syria_forcecapabilities.pdf [dostęp: 7.05.2018].

10 M. Lakomy, op.cit., s. 227. 
w ramach Ligii Państw Arabskich, która zainicjowała pomysł zawieszenia Damaszku w prawach członka organizacji ${ }^{11}$. Należy zwrócić uwagę, że sama wojna w Syrii uwidoczniła jak podejście państw Ligii wobec kwestii syryjskiej się różni. Oprócz zawieszenia Syrii w prawach członka, nałożono na nią sankcje, takie jak zamrożenie aktywów państwowych zagranicą, zaprzestanie transakcji z bankiem centralnym, czy zawieszenie inwestycji w Syrii, mimo sprzeciwu Jemenu i Libanu.

Zaangażowanie Królestwa w wojnę domową w Syrii oparte jest na dwóch poziomach, nakładających się na siebie: religijnym i geopolitycznym. Pod pierwszym względem Arabia Saudyjska stoi w opozycji do rządu syryjskiego. Królestwo jest arabskim krajem sunnickim, którego system społeczno-polityczny oparty jest na prawie szariatu i doktrynie wahhabizmu, natomiast Syria jest reżimem świeckim, a sam Baszar al-Asad jest alawitą, co stanowi jednoznaczną przesłankę do powołania przez Arabię Saudyjską koalicji antysyryjskiej. Syryjscy alawici często określani są przez wahhabickich teologów w Arabii Saudyjskiej jako heretycy i często wzywano do podjęcia dżihadu przeciwko nim ${ }^{12}$. Na płaszczyźnie geopolitycznej problem stanowi to, że Syria jest państwem sojuszniczym szyickiego Iranu, więc utrzymanie się przy władzy al-Asada oznaczałoby zdobycie przez Teheran dominacji w regionie, czemu Arabia Saudyjska się sprzeciwia ${ }^{13}$, w związku z czym, Syria stała się kolejnym miejscem irańsko-saudyjskiej proxy war.

15 sierpnia 2012 r. w Mekce odbyła się nadzwyczajna sesja Organizacji Współpracy Islamskiej, podczas której podjęto temat wojny w Syrii. Egipt zaproponował stworzenie specjalnego kwartetu ds. rozwiązania konfliktu w Syrii, w skład której wszedłby Egipt, Turcja, Iran i Arabia Saudyjska. Strategiczną rolę w rozmowach pokojowych miał mieć Iran, na co nalegał Kair, który uważał Teheran za jeden z najważniejszych podmiotów zaangażowanych w wojnę syryjską. Koncepcja ta była sprzeczna ze zdaniem Waszyngtonu i Rijadu. Waszyngton odmówił przyjęcia Iranu do powstałej

11 M. Hyra, Zaangażowanie Arabii Saudyjskiej w aktualne konflikty na Bliskim Wschodzie - przyczyny i perspektywy, ,Przegląd Geopolityczny” 2016, nr 17, s. 52-53.

12 M. Balcerzak, Przebieg wielkiej rewolucji ludów arabskich na przykładzie: Tunezji, Egiptu, Libii i Syrii, [w:] Middle East and North Africa: MENA źródtem szans i zagrożeń bezpieczeństwa, red. J. Treska, Gdynia 2012, s. 297.

13 M. Münnich, Syria wiosna 2015. Spojrzenie niepoprawne politycznie, Lublin 2015, s. 54-55 . 
wcześniej tzw. Grupy Przyjaciół Syrii, natomiast Rijad zbojkotował pierwszy szczyt kwartetu, powołując się na brak chęci współpracy ze strony Ira$n u^{14}$.

Wydarzenia w Syrii były zaskoczeniem dla Białego Domu, który od początku Arabskiej Wiosny obserwował sytuację na Bliskim Wschodzie. Stany Zjednoczone od kilkunastu lat prowadziły politykę izolacji Syrii na arenie międzynarodowej, co było uwarunkowane oskarżeniami wobec Damaszku o wspieranie międzynarodowego terroryzmu oraz o dążenia reżimu al-Asada do pozyskania broni masowej zagłady ${ }^{15}$. Co ciekawe, w pierwszej dekadzie XXI wieku, Damaszek próbował kilkakrotnie poprawić swoje relacje z Białym Domem, czego przykładem było poparcie przez Syrię w Radzie Bezpieczeństwa kontrowersyjnej rezolucji numer 1441 oraz 1511, dotyczących wojny w Iraku ${ }^{16}$. Wojna w Iraku w percepcji Waszyngtonu miała mieć także wpływ na sytuację wewnętrzną w Syrii. Administracja George'a W. Busha zakładała, że wojna w Iraku pobudzi syryjską opozycję do zwiększenia aktywności, a dodatkowo sankcje wobec Damaszku wprowadzone na podstawie Syria Accountablity Act, przyczynią się do upadku reżimu al-Asada. Do stosunkowej poprawy relacji amerykańsko-syryjskich doszło w 2007 r., kiedy to Syria brała udział w konferencji w Szarm el-Szejk oraz w Annapolis. Warto zwrócić uwagę na to, dlaczego Syria jest tak ważna dla Białego Domu. Reżim al-Asadów od kilkudziesięciu lat jest sojusznikiem zarówno Moskwy, jak i Teheranu, co skłania każdą administrację w Waszyngtonie do określenia swojej polityki wobec Damaszku, jako miejsca rywalizacji o wpływy oraz znaczenia Syrii dla bezpieczeństwa jednego z najważniejszych sojuszników Stanów Zjednoczonych na Bliskim Wschodzie - Izraela. Wydarzenia Arabskiej Wiosny skłoniły administrację Baracka Obamy do określenia nowej polityki nie tylko wobec samej Syrii, ale całego Bliskiego Wschodu i Afryki Północnej, co wpłynęło także na relacje Waszyngtonu z Rijadem.

14 E. Ragab, Relacje GCC z krajami MENA w okresie Arabskiej Wiosny, [w:] Fale Tunisami: kontestacja arabska w latach 2011-2013, red. R. Potocki, M. Piskorski, W. Hładkiewicz, Warszawa 2014, s. 128-129.

15 US expands 'axis of evil', news.bbc.co.uk/2/hi/americas/1971852.stm [dostęp: 12.07.2018].

16 R. Fiedler, Od przywództwa do hegemonii. Stany Zjednoczone wobec bliskowschodniego obszaru niestabilności w latach 1991-2009, Poznań 2010, s. 187. 
Wojna domowa w Syrii uwidoczniła różnice w podejściu Waszyngtonu i Rijadu do sytuacji na Bliskim Wschodzie. Pomimo iż 18 maja 2011 r. prezydent Barack Obama podpisał dekret, zgodnie z którym zamrożono aktywa syryjskie i zabroniono kontaktów biznesowych z prezydentem al-Asadem $^{17}$, w przeciwieństwie do swojego poprzednika, George'a W. Busha był zwolennikiem wycofywania wojsk amerykańskich z Bliskiego Wschodu, czemu sprzeciwiała się nie tylko Arabia Saudyjska, ale także Izrael, które próbowały nakłonić amerykańskiego prezydenta do zbrojnej interwencji w Syrii. Zarówno Rijad, jak i Tel Awiw widzą w rządzie syryjskim i wspierającej go Islamskiej Republice Iranu największego wroga w regionie oraz zagrożenie dla bezpieczeństwa międzynarodowego. Królestwo i monarchie z Rady Współpracy Zatoki Perskiej krytycznie oceniły brak podjęcia konkretnych kroków przez Baracka Obamę w kwestii rozwiązania konfliktu w Syrii1 ${ }^{18}$. Zwraca się uwagę na to, że polityka Waszyngtonu w czasie prezydentury Baracka Obamy wobec konfliktu w Syrii była oparta na koncepcji kontrolowanego chaosu, która polega na realizowaniu swoich interesów bez militarnego zaangażowania, co stanowi przeciwieństwo koncepcji realizowanej przez republikańskie rządy USA, które do realizacji interesów wykorzystywały kontyngenty wojskowe ${ }^{19}$. Administracja Baracka Obamy była świadoma, że kolejna amerykańska interwencja na Bliskim Wschodzie przyczyni się do wzrostu nastrojów antyamerykańskich, a także fundamentalizmów w społeczeństwach arabskich ${ }^{20}$. Dodatkowo, konflikt w Syrii zbiegł się w czasie z procesem wycofywania wojsk amerykańskich z Iraku w 2011 r. oraz zakończeniem misji International Security Assistance Force w Afganistanie w 2014 r. Znaczący wpływ na decyzję Baracka Obamy o niezaangażowaniu militarnym w Syrii był alians al-Asada

17 K. Czornik, Bliski Wschód w polityce zagranicznej Stanów Zjednoczonych w latach 1945-2012, Katowice 2012, s. 42.

18 P. Osiewicz, Analiza porównawcza stanowisk Rady Wspótpracy Zatoki Perskiej i poszczególnych państw członkowskich wobec konfliktu w Syrii, [w:] Bliski Wschód w procesie przemian. Tom 1, red. A. Bryc, M. Dahl, M. Lewicka, Toruń 2014, s. 251.

19 K. Sawiński, Konflikt syryjski: od „,kontrolowanego chaosu” do „wojny IV generacji”, [w:] Fale Tunisami: kontestacja arabska w latach 2011-2013, red. R. Potocki, M. Piskorski, W. Hładkiewicz, Warszawa 2014, s. 164.

20 G. Yacob, Konflikt syryjski-tło polityczne i następstwa, ,Rocznik Strategiczny 2015/2016” 2016, s. 331. 
z Kremlem, co w przypadku amerykańskiej interwencji mogłoby stać się impulsem do bezpośredniego konfliktu między Waszyngtonem a Moskwą. Ponadto z perspektywy wizerunkowej, Barack Obama nie chciał dopuścić do udziału sił amerykańskich w Syrii ze względu na Pokojową Nagrodę Nobla, której laureatem został w 2009 roku²1. Interwencji państw zachodnich sprzeciwia się także Syryjska Rada Narodowa, która wielokrotnie podkreślała suwerenność państw arabskich i skupiła się na propozycjach Ligii Państw Arabskich, jako organu uprawnionego do rozstrzygania sporów i konfliktów w świecie arabskim ${ }^{22}$. Waszyngton nie określił wojny w Syrii jako zagrożenia, które może bezpośrednio dotyczyć bezpieczeństwa Stanów Zjednoczonych. Ważniejsza z ówczesnej perspektywy Waszyngtonu była dalsza walka z Al-Kaidą, zapewnienie bezpieczeństwa Izraelowi oraz negocjacje z Iranem w sprawie programu nuklearnego.

W 2013 r. były ambasador Arabii Saudyjskiej w USA, książę Bandar bin Sultan stwierdził, że Królestwo będzie musiało dokonać znaczących zmian w relacjach z USA w związku z bezczynnością USA wobec Syrii, natomiast książę Turki bin Fajsal Al-Saud nazwał amerykańską politykę wobec Syrii godną pożałowania ${ }^{23}$. W odpowiedzi na nieudolność Waszyngtonu w kwestii rozwiązania problemu syryjskiego, w październiku $2012 \mathrm{r}$. Arabia Saudyjska krótko po wybraniu jej niestałym członkiem Rady Bezpieczeństwa ONZ, złożyła swój mandat, co stanowiło pierwszy taki przypadek w historii tego organu ${ }^{24}$.

12 listopada 2012 r. Arabia Saudyjska uznała powstałą w Dousze Syryjską Koalicję Narodową na rzecz Opozycji i Sił Rewolucyjnych za prawowitego przedstawiciela narodu syryjskiego ${ }^{25}$. Nigdy wcześniej Saudowie nie poparli otwarcie rebeliantów walczących z rządem kraju arabskiego. Arabia Saudyjska stanęła przeciwko reżimowi Asada wspólnie z Katarem,

21 R. Ożarowski, op.cit., s. 160-161.

22 N. Bahlawan, Arabska Wiosna w Syrii i jej reperkusje w regionie Bliskiego Wschodu, „Krakowskie Studia Międzynarodowe” 2012, nr 1, s. 175.

23 A. Viden, Is the Saudi-U.S. Relationship 'Broken"?, http://www.e-ir.info/2014/05/09/ is-the-saudi-u-s-relationship-broken/ [dostep: 07.204.2018].

24 M. Hyra, Wptyw Arabskiej Wiosny na politykę Królestwa Arabii Saudyjskiej, [w:] Polityka państw azjatyckich: wyzwania i dylematy, red. J. Marszałek-Kawa, J.K. Helnarska, Toruń 2015, s. 175.

25 M. Milczanowski, Z. Sawicka , Dwa odcienie rewolucji arabskiej: Egipt i Syria, Oświęcim 2013, s. 108. 
kiedy to oba państwa ustanowiły specjalny fundusz, z którego zdecydowano się opłacać żołd dezerterom z armii syryjskiej ${ }^{26}$.

Nie tylko Rijad udzielał pomocy syryjskim rebeliantom. Waszyngton również próbował wykorzystać sytuację w Syrii do ingerencji w sprawy wrogiego reżimu. Stany Zjednoczone udzielały wsparcia sunnickim rebeliantom, których określały mianem umiarkowanej opozycji lub pokojowych demonstrantów, a także uznały Syryjską Koalicję Narodową na rzecz Opozycji i Sił Rewolucyjnych za jedynego przedstawiciela Syryjczyków. Stany Zjednoczone oraz Arabia Saudyjska wspierając siły opozycyjne w Syrii korzystały ze współpracy z Turcją, która stanowiła dla Waszyngtonu i Rijadu zaplecze militarne. CIA z terenów południowej Turcji przekazywała syryjskiej opozycji sprzęt służący do łączności oraz broń przeciwpancerną. Rijad we współpracy z Katarem przez terytorium Turcji przekazywał rebeliantom przede wszystkim zakupioną na rynku wtórnym broń produkcji rosyjskiej ${ }^{27}$. W początkowej fazie konfliktu, Stany Zjednoczone wspierały Wolną Armię Syryjską, czyli największe opozycyjne ugrupowanie militarne w Syrii, jednak w 2013 r. w wyniku coraz częstszych doniesień związanych z tym, że na terenach kontrolowanych przez Wolną Syryjską Armię dochodzi do kradzieży, gwałtów i tortur na cywilach, straciła ona wiarygodność w oczach Waszyngtonu ${ }^{28}$. Z tego względu w grudniu 2013 r. Barack Obama sprzeciwił się propozycji CIA, by udzielić syryjskiej opozycji dostaw uzbrojenia i szkoleń wojskowych ${ }^{29}$.

Syria stała się miejscem rywalizacji o wpływy na Bliskim Wschodzie, głównie między Iranem wspieranym przez Rosję i Arabią Saudyjską wspieraną przez USA. Dostarczanie uzbrojenia przez obie strony do Syrii przyniosło wymierny skutek, ponieważ znaczna część sprzętu wojskowego trafiła w ręce dżihadystów oraz innych grup terrorystycznych. Pomimo iż,

26 A. Dzisiów-Szuszczykiewicz, Regionalna rywalizacja o Syrię, „Bezpieczeństwo Narodowe" 2012, nr II, s. 102.

27 M. Piskorski, Zasoby stron konfliktu syryjskiego i ich dynamika w latach 2011-2013, [w:] Fale Tunisami: kontestacja arabska w latach 2011-2013, red. R. Potocki, M. Piskorski, W. Hładkiewicz, Warszawa 2014, s. 205.

28 K. Pronińska, B. Balcerowicz, Konflikty zbrojne, „,Rocznik Strategiczny 2013/2014” 2014, s. 139-140.

29 M. Habowski, Polityka Stanów Zjednoczonych Ameryki wobec Bliskiego Wschodu w trakcie prezydentury Baracka Obamy, [w:] Konflikty zbrojne na Ukrainie i Bliskim Wschodzie: nowe wyzwania dla międzynarodowego bezpieczeństwa, red. M. Mróz, Wrocław 2015, s. 217. 
Rijad i Waszyngton wspierały sunnickich rebeliantów, ich interesy w Syrii znacznie się różniły. Królestwu zależało na obaleniu reżimu al-Asada i rządów alawitów oraz szyitów, tym samym na stworzeniu sunnickiego rządu w Damaszku, który odszedłby od sojuszu z Teheranem i Hezbollahem na rzecz współpracy z Rijadem. Waszyngtonowi zależało na stworzeniu demokratycznego rządu w Damaszku i poszanowaniu praw człowieka ${ }^{30}$.

20 sierpnia 2012 r. Barack Obama określił tzw. czerwoną linię dla sił syryjskich, której przekroczenie będzie równoznaczne z początkiem amerykańskiej interwencji w Syrii. Stany Zjednoczone miały rozpocząć operację militarną w Syrii, jeśli siły rządowe użyją broni chemicznej, do czego doszło 21 sierpnia 2013 r., kiedy armia syryjska wykorzystała sarin w ataku na poddamasceńską Ghutę ${ }^{31}$. Brak odpowiedzi Baracka Obamy na użycie przez siły reżimowe w Syrii broni chemicznej doprowadziły do pogorszenia relacji Stanów Zjednoczonych z Izraelem, Jordanią, Egiptem, Turcją oraz monarchiami znad Zatoki Perskiej, a w szczególności z Królestwem Arabii Saudyjskiej. Państwa muzułmańskie dążyły do tego, by obalić rząd Asada przy wykorzystaniu sił amerykańskich, tym samym nie biorąc znaczącego udziału w operacji militarnej, co szczególnie byłoby korzystne dla Arabii Saudyjskiej. Same relacje amerykańsko-saudyjskie w okresie prezydentury Baracka Obamy były napięte. Administracja Obamy uważała Królestwo za jednego ze swoich najbardziej kosztownych sojuszników, który dużo oczekuje od Waszyngtonu, a sam niewiele daje by współpracę między państwami rozwijać32

Arabia Saudyjska i Stany Zjednoczone współpracowały także w zakresie walki z tzw. Państwem Islamskim w Syrii i Iraku. Królestwo wielokrotnie podkreślało odpowiedzialność Stanów Zjednoczonych za powstanie i sukcesy tzw. Państwa Islamskiego ${ }^{33}$. W koncepcji Baracka Obamy, obalenie reżimu al-Asada stanowić miało ważne ogniwo w walce z samozwańczym

30 D. Michalik, Potęga kluczowych aktorów zaangażowanych w konflikt syryjski, [w:] Potęgometria. Tom 2, red. M. Sułek, Warszawa 2015, s. 49-50.

31 P. Sasnal, Pseudostabilizacja: problemy wspótczesnej polityki USA na Bliskim Wschodzie, Warszawa 2017, s. 286-287.

32 Arabia Saudyjska w tamtym okresie krytykowała działania zmierzające do porozumienia nuklearnego z Iranem, a sam Wielki Mufti Królestwa stwierdzał wówczas, że tzw. Państwo Islamskie jest częścią izraelskiej armii, kościoły powinny zostać zrównane z ziemią, P. Sasnal, op.cit., s. 288-289.

33 ISIS umiarkowanym zagrożeniem dla Arabii Saudyjskiej, http://bliskiwschod. pl/2014/11/isis-zagrozeniem-dla-arabii-saudyjskiej/ [dostęp: 8.05.2018]. 
kalifatem, co zostało potwierdzone także przez Rijad podczas międzynarodowej konferencji na temat bezpieczeństwa w Dżuddzie. Arabia Saudyjska poparła amerykańską koncepcję ataków powietrznych na pozycje kalifatu w Syrii i Iraku, nie wykluczając przy tym przyszłego militarnego zaangażowania państw skupionych w ramach Rady Współpracy Zatoki ${ }^{34}$. Jednakże działania Rijadu wobec tzw. Państwa Islamskiego są odbierane dwojako, ponieważ z jednej strony Arabia Saudyjska wspiera działania mające na celu walkę z dżihadystami, którzy wielokrotnie zapowiadali obalenie rodziny Saudów oraz zniszczenie Mekki i Medyny, ale z drugiej strony Rijad nie sprzeciwia się działaniom Państwa Islamskiego skierowanym przeciwko szyitom $^{35}$. Co ciekawe, od połowy 2014 r. Waszyngton ściśle kooperował w celu zwalczenia kalifatu nie z Arabią Saudyjską, która także działała na tym polu, ale przede wszystkim z syryjskimi i irackimi Kurdami oraz bojówkami szyickimi, którym udało się odbić około 30\% terenów zajmowanych przez dżihadystów w Syrii i ponad 50\% terenów w Iraku ${ }^{36}$.

Przejęcie tronu saudyjskiego przez Salmana bin Abdulaziza al-Sauda w 2015 r. doprowadziło do rozbudzenia aspiracji Rijadu do przejęcia przywództwa w świecie arabskim na Bliskim Wschodzie. Przejęcie władzy w Damaszku przez sunnickich rebeliantów stało się dla Arabii Saudyjskiej priorytetem w polityce zagranicznej na Bliskim Wschodzie, ponieważ umożliwiłoby to ograniczenie aspiracji mocarstwowych Islamskiej Republiki Iranu.

Przed zaangażowaniem Królestwa Arabii Saudyjskiej w Syrii istniało wiele problemów, takich jak brak bezpośredniego sąsiedztwa z Syrią, czy też rozdrobnienie frakcji rebelianckich walczących w konflikcie syryjskim ${ }^{37}$. Ugrupowania te mają różnych sponsorów i są związane z kilkoma podmiotami zaangażowanymi w wojnę syryjską, takimi jak Stany Zjednoczone, Katar i Turcja, przez co Rijad nie może mieć wpływu na wszystkie frakcje sunnickie biorące udział w konflikcie ${ }^{38}$.

34 J. Sławek, Rada Wspótpracy Państw Zatoki - jaka przyszłość po Arabskiej Wiośnie?, „Krakowskie Studia Międzynarodowe”2014, nr 3, s. 160.

35 P. Osiewicz, op.cit., s. 257-258.

36 P. Sasnal, op.cit., s. 290.

37 Wśród ugrupowań walczących w konflikcie syryjskim można wyróżnić m.in. tzw. Państwo Islamskie, Wolną Armię Syryjską, Bractwo Muzułmańskie, Dżabhat an-Nusra czy Hizb at-Tahrir.

38 M. Münnich, op.cit., s. 57. 
W grudniu 2015 r. w Rijadzie pod przewodnictwem Arabii Saudyjskiej odbyło się spotkanie syryjskich grup opozycyjnych, których nie uznano za organizacje terrorystyczne. Celem spotkania było określenie wspólnego stanowiska przed planowanymi na styczeń 2016 r. rozmowami pokojowymi. Szczyt z syryjską opozycją miał dla Arabii Saudyjskiej znaczenie prestiżowe, z tego względu, że udowodniono, że opozycja w Syrii jest zjednoczona i ma wizję rozwiązania konfliktu we współpracy z Królestwem ${ }^{39}$.

15 grudnia 2015 r. Arabia Saudyjska utworzyła islamską koalicję antyterrorystyczną, której głównym celem według Mohammeda bin Salmana Al-Sauda było zwalczanie terroryzmu na terenach przejętych przez samozwańczy kalifat ${ }^{40}$. Arabia Saudyjska chciała mieć większy wpływ na to, co się dzieje w regionie i tym samym stać się liderem świata muzułmańskiego, w związku z czym stanęła na czele koalicji 34 państw muzułmańskich ${ }^{41}$. Saudyjski minister obrony podkreślił w lutym 2016 r., że saudyjskie siły zbrojne mają doświadczenie w prowadzeniu kampanii lądowej, które zdobyły w Jemenie ${ }^{42}$ i są w stanie rozpocząć działania wojenne w Syrii, jeśli tylko Waszyngton wyrazi na to zgodę. Biały Dom odniósł się pozytywnie do propozycji ze strony Królestwa, argumentując to tym, że kampania powietrzna nie jest wystarczająca w walce $\mathrm{z}$ kalifatem, a rozpoczęcie działań lądowych mogłoby się przyczynić do szybszego pokonania tzw. Państwa Islamskiego. Stany Zjednoczone w grudniu 2016 r. ogłosiły wysłanie do Syrii ponad 200 żołnierzy w celu walki z dżihadystami, co miało również stanowić podstawę do przyszłej kampanii lądowej z siłami koalicji muzułmańskiej pod przywództwem Rijadu ${ }^{43}$.

39 M. Hyra, Zaangażowanie Arabii Saudyjskiej..., op.cit., s. 54-55.

40 S. Wojciechowski, Terroryzm - stare i nowe dylematy, , Rocznik Strategiczny 2015/2016” 2016, s. 409.

41 W operacji antyterrorystycznej kierowanej przez Arabię Saudyjską nie wzięła udziału Islamska Republika Iranu, M. Mruk, Królestwo Arabii Saudyjskiej pod rzadami Salmana bin Abdulaziza Al-Sauda - próby budowy nowoczesnego mocarstwa regionalnego, [w:] Monarchia. Idea, historia, perspektywy, red. K. Kofin, M. Kofin, Kraków 2018, s. 257.

42 Saudi Arabia willing to send ground troops to Syria, http://www.aljazeera.com/ news/2016/02/general-saudi-arabia-set-deploy-troops-syria-160205042542486.html [dostęp: 9.05.2018].

43 Saudi Arabia 'ready to send ground troops' to Syria, https://www.alaraby.co.uk/english/ News/2017/2/21/Saudi-Arabia-ready-to-send-ground-troops-to-Syria, [dostęp: 8.05.2018]. 


\section{Sytuacja w Syrii w latach 2017-2018 - zmiana czy kontynuacja polityki Arabii Saudyjskiej i Stanów Zjednoczonych?}

Początek 2017 r. przyniósł zmianę na stanowisku prezydenta Stanów Zjednoczonych, ponieważ na czele supermocarstwa stanął Donald Trump. Czterdziesty piąty prezydent Stanów Zjednoczonych już w czasie kampanii wyborczej krytykował opieszałość administracji Baracka Obamy co do działań zmierzających do zakończenia wojny w Syrii, ale co ciekawe, krytykował także sojusz amerykańsko-saudyjski. Trump przed przejęciem władzy w Stanach Zjednoczonych wielokrotnie podkreślał, że Arabia Saudyjska powinna udzielić wsparcia militarnego w walce z tzw. Państwem Islamskim, a jeśli Rijad nie zgodzi się na współpracę, Waszyngton wstrzyma import ropy naftowej z Królestwa, które także powinno zapłacić Stanom Zjednoczonym za stacjonowanie tam amerykańskich sił zbrojnych. Jednak do zmiany polityki Donalda Trumpa wobec Arabii Saudyjskiej doszło tuż po zaprzysiężeniu na stanowisko prezydenta Stanów Zjednoczonych, kiedy to w maju 2017 r. doszło do oficjalnej wizyty amerykańskiego prezydenta w Rijadzie. Podczas wizyty Donalda Trumpa w Królestwie, podpisano umowy handlowe między Stanami Zjednoczonymi a Arabią Saudyjską o wysokości 350 miliardów dolarów, z tego za 110 miliardów dolarów Rijad miał zakupić najnowocześniejsze uzbrojenie ${ }^{44}$.

Wraz ze zmianą polityki Waszyngtonu wobec Rijadu, doszło do zmiany polityki wobec wojny domowej w Syrii. Donald Trump w przeciwieństwie do swojego poprzednika jest zwolennikiem bardziej zdecydowanych kroków wobec reżimu al-Asada oraz tzw. Państwa Islamskiego. 7 kwietnia 2017 r. decyzją prezydenta Donalda Trumpa doszło do ataku lotniczego na syryjską bazę lotniczą Al-Szajrat, podczas którego wykorzystano 59 pocisków samosterujących Tomahawk ${ }^{45}$. Amerykański atak był odpowiedzią

44 Ważnym jest to, że wizyta Donalda Trumpa w Rijadzie zbiegła się w czasie z wyborami prezydenckimi w Iranie, a także z katarskim kryzysem dyplomatycznym, który rozpoczął się kilkanaście dni później, J. Sabak, Trump podpisat w Arabii Saudyjskiej umowy warte 350 mld dolarów. 110 mld na amerykańską broń, http://www.defence24.pl/trump-podpisal-w-arabiisaudyjskiej-umowy-warte-350-mld-dolarow-110-mld-na-amerykanska-bron [dostęp: 10.05.2018].

45 P. Sasnal, Komentarz PISM: Atak USA na bazę Al-Szajrat w Syrii, http://www.pism.pl/ publikacje/komentarz/nr-1-2017\# [dostęp: 10.05.2018]. 
na użycie przez al-Asada broni chemicznej przeciwko ludności cywilnej w Chan Szajchun. Atak Stanów Zjednoczonych uzyskał poparcie Arabii Saudyjskiej oraz innych państw regionu, a sama decyzja Donalda Trumpa o zdecydowanej odpowiedzi na użycie chroni chemicznej przez siły reżimu miała stanowić potwierdzenie gotowości do działania sił Stanów Zjednoczonych oraz realizacji zobowiązań sojuszniczych. Należy zauważyć, że pomimo napięć między Waszyngtonem a Moskwą, Władimir Putin został poinformowany o planowanym ataku na syryjską bazę i został ostrzeżony, by wycofał swoje siły z owej bazy ${ }^{46}$.

Do kolejnego ataku na Syrię doszło w nocy z 13 na 14 kwietnia 2018 r., kiedy to siły amerykańskie, francuskie i brytyjskie dokonały nalotów na pozycje w Damaszku, gdzie zniszczono laboratorium, w którym prowadzono badania nad bronią chemiczną oraz dwa schrony w okolicach Hims, w których miał być składowany sarin. Atak zjednoczonych sił amerykańsko-francusko-brytyjskich był odpowiedzią na użycie przez siły Baszara al-Asada broni chemicznej przeciwko ludności cywilnej w mieście $\mathrm{Homs}^{47}$. Atak ten uzyskał także wsparcie ze strony Arabii Saudyjskiej oraz innych państw Zatoki - Bahrajnu i Zjednoczonych Emiratów Arabskich.

Kilka dni po atakach lotniczych, powrócił temat zaangażowania regularnej armii amerykańskiej w Syrii. Donald Trump pomimo podjętych wcześniej kroków, wyszedł z koncepcją wysłania do Syrii koalicji wojsk arabskich, jednak minister spraw zagranicznych Arabii Saudyjskiej, Adel al-Jubeir stwierdził, że takie działanie może tylko pogorszyć sytuację w Syrii. Dodatkowo Rijad, który jest zaangażowany w wojnę w Jemenie, coraz częściej odczuwa negatywne skutki interwencji u swojego południowego sąsiada, a wysłanie sił do Syrii będzie równoznaczne z otoczeniem saudyjskiego wojska przez wrogie siły szyickiego Iranu oraz Hezbollahu, co postawiłoby Królestwo w niewygodnej pozycji i mogłoby być impulsem do bezpośredniego konfliktu z Teheranem ${ }^{48}$.

46 P. Milewski, Amerykanie zaatakowali Syrię, http://www.newsweek.pl/swiat/polityka/ atak-usa-na-syrie-amerykanie-zaatakowali-syrie,artykuly,408416,1.html [dostęp: 10.05.2018].

47 Atak na Syrię: „Misja wypetniona”? Trump się ttumaczy, http://www.rp.pl/Wojnaw-Syrii/180419573-Atak-na-Syrie-Misja-wypelniona-Trump-sie-tlumaczy.html [dostęp: 10.05.2018].

48 J. Borger, Syria: proposal to replace US troops with Arab force comes with grave risks, https://www.theguardian.com/us-news/2018/apr/18/us-syria-arab-force-replace-americantroops-saudi-arabia-egypt-uae [dostęp: 10.05.2018]. 
Przełom 2017 i 2018 r. to okres, w którym Królestwo Arabii Saudyjskiej ograniczyło swoją aktywność militarną w Syrii. Deklarowana od 2016 r. chęć stworzenia arabskiej koalicji sił lądowych w Syrii pod kierownictwem Rijadu pozostaje w sferze deklaratywnej, co jest nadal podkreślane w oficjalnych komunikatach władz saudyjskich. W kwietniu 2018 r. saudyjski minister spraw zagranicznych Adel al-Jubeir potwierdził dalszą chęć wysłania sił lądowych z Królestwa do Syrii. Minister al-Jubeir podkreślił, że inicjatywa Arabii Saudyjskiej dotycząca działań lądowych w Syrii nie jest czymś nowym, ponieważ pomysł ten był wielokrotnie przedstawiany administracji Baracka Obamy, jednak nie doczekał się on faktycznej realizacji. W kwietniu 2018 r. Królestwo ponowiło swoją propozycję wysłania wojsk do ogarniętej wojną w Syrii, co było przede wszystkim skutkiem medialnych doniesień o tym, że prezydent Donald Trump chciałby połączyć siły lądowe Arabii Saudyjskiej i Zjednoczonych Emiratów Arabskich, mające zastąpić amerykańskie wojsko, które miałoby zostać wycofane z terenów syryjskich ${ }^{49}$.

Toczący się konflikt w Syrii stanowi współcześnie jeden z najważniejszych problemów dla bezpieczeństwa międzynarodowego w regionie Bliskiego Wschodu. W Syrii krzyżują się interesy zarówno państw regionu, ale także USA, Rosji, Chin i państw europejskich. Tak duża liczba aktorów zaangażowanych w konflikt nie przyczynia się do zahamowania rozlewu krwi, wręcz przeciwnie, powoduje powstanie kolejnych frakcji, które dążą do przejęcia władz w Damaszku. Wojna w Syrii determinuje także sytuację na Bliskim Wschodzie i przyczynia się do wzrastającej rywalizacji między Rijadem a Teheranem. Odsuwa również w czasie rozwiązanie problemu konfliktu palestyńsko-izraelskiego, co wpływa na relacje USA i Arabii Saudyjskiej, które - pomimo rozbieżności w kwestii sposobu rozwiązania konfliktu w sferze militarnej - dążą do ustabilizowania sytuacji w Syrii i na Bliskim Wschodzie.

Warto zadać pytanie, jak w najbliższym czasie będzie kształtować się amerykańskie i saudyjskie zaangażowanie w Syrii? Zarówno przed Stanami Zjednoczonymi, jak i Arabią Saudyjską stoi wiele wyzwań dla ich bez-

49 Saudi in talks with US over troop deployment in Syria, https://www.aljazeera. com/news/2018/04/saudi-talks-troop-deployment-syria-180417193232765.html [dostęp: 12.07.2018]. 
pieczeństwa. Nierozwiązany katarski kryzys dyplomatyczny, zapomniana przez społeczność międzynarodową wojna domowa w Jemenie, napięcia izraelsko-palestyńskie i przede wszystkim problem aspiracji nuklearnych Iranu $^{50}$ stanowią kierunki, które determinują politykę Waszyngtonu i Rijadu w ostatnim czasie. Dodatkowo, Arabia Saudyjska od czasu wyznaczenia przez króla Salmana na następcę tronu swojego syna, Mohammeda, weszła na drogę reform wewnętrznych, przez co jej aktywność międzynarodowa w ostatnim czasie nie jest już aż tak duża.

Pomimo wyżej wymienionych wyzwań dla polityki Stanów Zjednoczonych i Arabii Saudyjskiej, państwa te nie zrezygnują w pełni z zaangażowania w Syrii, nawet jeśli nie w celu obalenia reżimu Baszara al-Asada, to po to, by ograniczyć poszerzanie wpływów w regionie przez Federację Rosyjską i Islamską Republikę Iranu.

\section{Zakończenie}

Wojna w Syrii jest przede wszystkim sprawdzianem dla sojuszu amerykańsko-saudyjskiego, który dotychczas był określany mianem strategicznego. Zarówno Arabia Saudyjska, jak i Stany Zjednoczone uznają rządzoną przez Baszara al-Asada Syrię za zagrożenie dla bezpieczeństwa międzynarodowego oraz dla swoich interesów, co uwarunkowane jest przede wszystkim faktem, że Damaszek od kilkudziesięciu lat jest jednym z najważniejszych bliskowschodnich sojuszników Federacji Rosyjskiej oraz Islamskiej Republiki Iranu. Szczególnie rola Iranu w wojnie syryjskiej determinuje politykę Rijadu i Waszyngtonu wobec Damaszku. Iran jest obecnie największym wrogiem Saudów oraz Białego Domu, a jego obecność w Syrii pozwala na powiększanie irańskiej strefy wpływów w regionie, a także zbliżanie się sił irańskich do sił saudyjskich i amerykańskich, co generuje napięcia w relacjach między Teheranem a Rijadem i Waszyngtonem. Syria obecnie jest jednym z kolejnych miejsc, w których toczy się wojna zastępcza mię-

508 maja 2018 r. Donald Trump wypowiedział Joint Comprehensive Plan of Action, czyli dokument potocznie określany jako porozumienie nuklearne z Iranem, które grupa P5+1 podpisała z Iranem 14 lipca 2015 r. oraz zapowiedział ponowne nałożenie sankcji gospodarczych na Teheran, Trump wycofuje się z umowy z Iranem. Merkel, Macron i May prosili, by tego nie robit, http://www.newsweek.pl/swiat/polityka/trump-wycofuje-sie-z-umowy-ziranem,artykuly,426955,1.html [dostęp: 10.05.2018]. 
dzy państwami walczącymi o hegemonię na Bliskim Wschodzie. Należy zwrócić uwagę na fakt, że nie tylko kwestia irańska jest elementem spajającym politykę Królestwa i Stanów Zjednoczonych wobec Syrii, ale także istnienie tzw. Państwa Islamskiego. Oba państwa nieustannie od 2014 r. podejmują wspólne działania mające na celu zwalczenie samozwańczego kalifatu na terytorium Syrii i Iraku, przede wszystkim wykorzystując siły militarne, ale także wspierając siły opozycyjne biorące udział w konflikcie. Jednakże, samo istnienie tak dużej ilości frakcji walczących w wojnie w Syrii powoduje napięcia na linii Rijad-Waszyngton. Oba państwa chcąc mieć większy wpływ na to co się dzieje w Syrii, wspierają różne, często walczące przeciw sobie oddziały co pogłębia chaos oraz destabilizuje państwo. Zarówno Saudowie, jak i amerykańska administracja mają odmienne wizje powojennej Syrii, co powoduje, że żadne z proponowanych rozwiązań nie uzyskują poparcia większości społeczności międzynarodowej, której zależy na stabilizacji sytuacji w Syrii i na Bliskim Wschodzie.

Reasumując, należy zadać pytanie o efektywność działań Arabii Saudyjskiej oraz Stanów Zjednoczonych w wojnie domowej w Syrii. Polityka Rijadu i Waszyngtonu od 2011 roku uległa ewolucji i zmianie. Początkowo oba państwa obserwowały sytuację w Syrii, najpierw podczas masowych protestów, a następnie w czasie konfliktu zbrojnego, którego krwawy przebieg zmusił je do podjęcia reakcji zbrojnej. Działania Królestwa i Stanów Zjednoczonych w Syrii podejmowane od kilku lat nie należą do skutecznych, co jest wynikiem przede wszystkim braku wspólnej wizji obu państw, co do sposobu zakończenia konfliktu, a także tego, jak Syria miałaby wyglądać w powojennej rzeczywistości. Dodatkowo, brak efektywności działań Rijadu i Białego Domu jest skutkiem aktywności dużej ilości podmiotów stosunków międzynarodowych w Syrii, które posiadają swoje interesy w tym państwie i dążą do ich realizacji, nawet kosztem międzynarodowego bezpieczeństwa. Zmieniająca się sytuacja międzynarodowa ma także zasadniczy wpływ na efektywność polityki Stanów Zjednoczonych i Królestwa wobec Damaszku, w szczególności zaangażowanie Rijadu w Jemenie, które pociąga za sobą także znaczne straty finansowe dla Saudów, co wpływa na ograniczenie aktywności w Syrii. Od początku 2018 r. oba państwa skupiły się na innych wyzwaniach dla ich bezpieczeństwa, przede wszystkim na problemie irańskim oraz kwestii koreańskiej, która w ostatnich tygodniach czerwca 2018 
r. stała się jednym z najważniejszych tematów w debacie międzynarodowej, odsuwając tym samym problem syryjski na dalszy plan. Obecnie temat wojny w Syrii nie jest już tak często podejmowany w debacie o bezpieczeństwie międzynarodowym, gdzie na pierwszy plan wysuwają się inne wydarzenia, przez co społeczność międzynarodowa coraz częściej odsuwa w czasie podjęcie kroków w celu zakończenia konfliktu.

\section{Bibliografia}

Atak na Syrię: "Misja wypetniona”? Trump się ttumaczy, http://www. rp.pl/Wojna-w-Syrii/180419573-Atak-na-Syrie-Misja-wypelniona-Trump-sie-tlumaczy.html.

Bahlawan N., Arabska Wiosna $w$ Syrii i jej reperkusje w regionie Bliskiego Wschodu, ,Krakowskie Studia Międzynarodowe” 2012, nr 1.

Balcerzak M., Przebieg wielkiej rewolucji ludów arabskich na przykładzie: Tunezji, Egiptu, Libii i Syrii, [w:] Middle East and North Africa: MENA źódtem szans i zagrożeń bezpieczeństwa, red. J. Treska, Gdynia 2012.

Borger J., Syria : proposal to replace US troops with Arab force comes with grave risks https://www.theguardian.com/us-news/2018/apr/18/us-syria-arab-force-replace-american-troops-saudi-arabia-egypt-uae.

Cordesman A.H., If Its Syria: Syrian Military Forces and Capabilities, http://csis.org/files/media/csis/pubs/syria_forcecapabilities.pdf.

Czajkowska K., Diawoł-Sitko A., Systemy polityczne wybranych państw Bliskiego Wschodu, Warszawa 2012.

Czornik K., Bliski Wschód w polityce zagranicznej Stanów Zjednoczonych w okresie pozimnowojennym, Katowice 2012.

Dzisiów-Szuszczykiewicz A., Regionalna rywalizacja o Syrię, „Bezpieczeństwo Narodowe" 2012, nr II.

Fiedler R., Od przywództwa do hegemonii. Stany Zjednoczone wobec bliskowschodniego obszaru niestabilności w latach 1991-2009, Poznań 2010.

Habowski M, Polityka Stanów Zjednoczonych Ameryki wobec Bliskiego Wschodu w trakcie prezydentury Baracka Obamy, [w:] Konflikty zbrojne na Ukrainie i Bliskim Wschodzie: nowe wyzwania dla międzynarodowego bezpieczeństwa, red. M. Mróz, Wrocław 2015. 
Hyra M., Wptyw Arabskiej Wiosny na polityke Królestwa Arabii Saudyjskiej, [w:] Polityka państw azjatyckich: wyzwania i dylematy, red. J. Marszałek-Kawa, J.K. Helnarska, Torun 2015.

Hyra M.,Zaangażowanie Arabii Saudyjskiej waktualne konfliktyna Bliskim Wschodzie - przyczyny i perspektywy, „Przegląd Geopolityczny” 2016, nr 17.

ISIS umiarkowanym zagrożeniem dla Arabii Saudyjskiej, http://bliskiwschod.pl/2014/11/isis-zagrozeniem-dla-arabii-saudyjskiej/.

Jomma F., System polityczny Syrii a „Arabska Wiosna Ludów”, [w:] Bunt czy rewolucja? Przemiany na Bliskim Wschodzie po 2010 roku, red. K. Górak-Sosnowska, K. Pachniak, Łódź 2012.

Lakomy M., Wewnętrzne i zewnętrzne uwarunkowania wojny domowej w Syrii, "Studia Polityczne" 2012, nr 31.

Landowski Z., Islam: nurty, odtamy, sekty, Warszawa 2008.

Michalik D., Potęga kluczowych aktorów zaangażowanych $w$ konflikt syryjski, [w:] Potegometria. Tom 2, red. M. Sułek, Warszawa 2015.

Milczanowski M., Sawicka Z., Dwa odcienie rewolucji arabskiej: Egipt i Syria, Oświęcim 2013.

Milewski P., Amerykanie zaatakowali Syrię, http://www.newsweek.pl/ swiat/polityka/atak-usa-na-syrie-amerykanie-zaatakowali-syrie,artykuly,408416,1.html.

Mruk M., Królestwo Arabii Saudyjskiej pod rządami Salmana bin Abdulaziza Al-Sauda - próby budowy nowoczesnego mocarstwa regionalnego, [w:] Monarchia. Idea, historia, perspektywy, red. K. Kofin, M. Kofin, Kraków 2018.

Münnich M., Syria wiosna 2015. Spojrzenie niepoprawne politycznie, Lublin 2015.

Osiewicz P., Analiza porównawcza stanowisk Rady Wspótpracy Zatoki Perskiej i poszczególnych państw członkowskich wobec konfliktu w Syrii, [w:] Bliski Wschód w procesie przemian. Tom 1, red. A, Bryc, M. Dahl, M. Lewicka, Torun 2014.

Ożarowski R., Motywacje i interesy państw zaangażowanych w wojnę w Syrii, [w:] Bliski Wschód między konfliktem a stabilizacją, red. J. Marszałek-Kawa, R. Podgórzańska, J. Piątek, Toruń 2017.

Piskorski M., Zasoby stron konfliktu syryjskiego i ich dynamika w latach 
2011-2013, [w:] Fale Tunisami: kontestacja arabska w latach 2011-2013, red. R. Potocki, M. Piskorski, W. Hładkiewicz, Warszawa 2014. Pronińska K., Balcerowicz B., Konflikty zbrojne, ,Rocznik Strategiczny 2013/2014" 2014.

Ragab E., Relacje GCC z krajami MENA w okresie Arabskiej Wiosny, [w:] Fale Tunisami: kontestacja arabska w latach 2011-2013, red. R. Potocki, M. Piskorski, W. Hładkiewicz, Warszawa 2014.

Sabak J., Trump podpisat w Arabii Saudyjskiej umowy warte $350 \mathrm{mld}$ dolarów. 110 mld na amerykańską broń, http://www.defence24.pl/trump-podpisal-w-arabii-saudyjskiej-umowy-warte-350-mld-dolarow110-mld-na-amerykanska-bron.

Sasnal P., Komentarz PISM: Atak USA na baze Al-Szajrat w Syrii, http:// www.pism.pl/publikacje/komentarz/nr-1-2017\#.

Sasnal P., Pseudostabilizacja: problemy współczesnej polityki USA na Bliskim Wschodzie, Warszawa 2017.

Saudi Arabia 'ready to send ground troops' to Syria, https://www.alaraby. co.uk/english/News/2017/2/21/Saudi-Arabia-ready-to-send-ground-troops-to-Syria.

Saudi Arabia willing to send ground troops to Syria, http://www.aljazeera.com/news/2016/02/general-saudi-arabia-set-deploy-troops-syria-160205042542486.html.

Saudi in talks with US over troop deployment in Syria, https://www.aljazeera.com/news/2018/04/saudi-talks-troop-deployment-syria-1804 17193232765.html.

Sawiński K., Konflikt syryjski: od „kontrolowanego chaosu” do „wojny IV generacji,, [w:] Fale Tunisami: kontestacja arabska w latach 2011-2013, red. R. Potocki, M. Piskorski, W. Hładkiewicz, Warszawa 2014.

Sławek J., Rada Wspótpracy Państw Zatoki - jaka przyszłość po Arabskiej Wiośnie?, „Krakowskie Studia Międzynarodowe”2014, nr 3.

Syria sends tanks onto street, http://www.aljazeera.com/news/middleea st/2011/04/20114255333825461.html.

Trump wycofuje się z umowy z Iranem. Merkel, Macron i May prosili, by tego nie robit, http://www.newsweek.pl/swiat/polityka/trump-wycofuje-sie-z-umowy-z-iranem, artykuly,426955,1.html.

US expands 'axis of evil', news.bbc.co.uk/2/hi/americas/1971852.stm. 
Wojciechowski S., Terroryzm - stare i nowe dylematy, ,Rocznik Strategiczny 2015/2016" 2016.

Viden A., Is the Saudi-U.S. Relationship 'Broken"?, http://www.e-ir.info/ 2014/05/09/is-the-saudi-u-s-relationship-broken/.

Yacob G., Konflikt syryjski-tto polityczne i następstwa, „Rocznik Strategiczny 2015/2016” 2016.

Zdanowski J., Bliski Wschód 2011: bunt czy rewolucja?, Kraków 2011.

\section{Politics of Saudi Arabia and the United States against the civil war in Syria - a convergence or divergence of interests?}

\section{Summary}

The policy of Saudi Arabia and the United States towards Syria since 2011 is full of paradoxes. On the one hand, both countries are in favor of overthrowing the regime of Bashar al-Assad and reducing the influence of Iran and Russia in Syria, but on the other hand there are discrepancies in the approach of Washington and Riyad to the Syrian question, which was particularly visible during the presidency of Barack Obama. The issue of financing the opposition groups fighting in Syria, but most of all the problem of launching land intervention in a war-stricken country was among the contentious issues. The Kingdom, as an advocate of intervention, has repeatedly called on Washington to take more decisive steps to overthrow al-Assad and combat the so-called Islamic State. However, the other problems facing the White House and Riyadh, which affect the solution of the Syrian question, are nowadays a priority in the policies of the United States and Saudi Arabia, in contrast to the war in Syria.

Keywords: Saudi Arabia, United States, Syria, civil war, caliphate

\section{Политика СауАовской Аравии и СоеАиненных Штатов против гражАанской войны в Сирии - сближение ими расхожАение интересов?}

\section{Резюме}

Политика Саудовской Аравии и Соединенных Штатов в отношении Сирии с 2011 года полна параАоксов. С оАной стороны, обе страны выступают за свержение режима Башара амь-Асада и снижения вмияния Ирана и России в Сирии, но, с Аругой стороны, существуют расхожАения в подходе Вашинг- 
тона и ариада к сирийскому вопросу, что особенно заметно в периоА президентства Барака Обамы. Среди спорных вопросов было финансирование оппозиционных групп, сражающихся в Сирии, но прежАе всего проблема инициирования вмешательства в землю в раздираемой войной стране. Королевство как сторонник вмешательства неоднократно призывало Вашингтон принять более решительные меры Аля свержения аль-Асада и искоренения так называемых Исламское государство. ОАнако другие проблемы, стоящие перед Белым Аомом и Эр-Риядом, которые влияют на решение сирийского вопроса, в настоящее время явцяются приоритетом в политике Соединенных Штатов и Саудовской Аравии, в отличие от войны в Сирии.

КАючевые слова: Саудовская Аравия, Соединенные Штаты, Сирия, гражАанская война, халифат

mgr Marzena Mruk

Zakład Stosunków Międzynarodowych

Instytut Nauk Politycznych i Dziennikarstwa

Wydział Nauk Społecznych

Uniwersytet Śląski w Katowicach

ul. Bankowa 11

40-007 Katowice

e-mail:marzenamruk93@wp.pl/mmruk@us.edu.pl 